Schenck CJ

\title{
PROBLEMS RURAL SOCIAL WORKERS EXPERIENCE
}

Prof Rinie Schenck is an Associate Professor in the Department of Social Work, Unisa.

The rural areas of our country represent the worst concentrations of poverty. No progress can be made towards a life of human dignity for our people as a whole unless we ensure the development of these areas (Thabo Mbeki, 1999).

\begin{abstract}
The research was an exploratory study of the views and experiences of 45 social workers related to their work and working conditions in rural communities This article describes the research results around aspects regarding problems that social workers experience when working in rural communities e.g problems of the rural community that the social worker needs to attend to and problems the social workers experience connected to their work situation in rural areas. It is hoped that this study will bring about an awareness and concern for the rural people and rural social workers who have to take up the challenges.
\end{abstract}

\section{INTRODUCTION}

To work in a rural area is not easy. What the social workers found difficult, according to Mayer (2001:95), is the lack of resources and of professional and family support. Ginsberg (1998) said that one of the paradoxes in working in a rural community is that, although there is a need for the services of a social worker, the social worker is not accepted by the people immediately. People in small communities operate in a highly personalised manner. They rely more on family, the church and friends and do not necessarily make use of the social workers as a first resource. The social workers have to work hard to build a relationship of trust with the people, create networks and resources, and gain community access and acceptance. These are some of the issues discussed by various authors dealing with the problems that rural social workers may experience (Gumpert \& Saltman, 1998; Lonne \& Cheers, 2000; Martinez-Brawley, 2000; Schafer, 1980).

\section{THE AIM OF THE RESEARCH}

This article aims to describe the research results around two aspects regarding problems that social workers experience when working in rural communities:

- problems of the rural community that the social worker needs to attend to; and

- problems the social workers experience connected to their work situation in rural areas. Living in a rural community has its own problems. (Schenck, 2003.)

\section{THE RESEARCH}

The research was an exploratory study of the views and experiences of social workers related to their work in rural communities. The research consisted of the following:

\section{Literature study}

The available literature on rural social work was mostly from the USA, UK and Australia and a few South African studies (Rankin, 1992; Taback \& Triechaardt, 1992; Woods, 1992). These references were used as a basis for compiling the guidelines for the interviews with the social 
workers. For the purpose of bench-marking the results of the research and the information from the literature, the literature will be discussed in the different sections.

\section{Interviews}

Interviews were conducted with 45 rural social workers from five different provinces in South Africa during the period March 2002 to October 2002.

\section{THE FEEDBACK FROM THE SOCIAL WORKERS REGARDING PROBLEMS RURAL COMMUNITIES EXPERIENCE}

\section{Problems in rural areas}

The social workers were asked to name the problems that they perceive to be present in the communities where they work. This does not necessarily refer to the problems that people bring to the social workers, but rather to the social workers' observations. These problems can be organised into the following themes:

TABLE 1

PROBLEMS

\begin{tabular}{|l|c|c|}
\hline \multicolumn{1}{|c|}{ Problems mentioned } & Number & Percentage (\%) \\
\hline 1. Aids/orphans & 39 & 87 \\
\hline 2. Illiteracy & 9 & 20 \\
\hline 3. Unemployment & 19 & 42 \\
\hline 4. Health & 2 & 4 \\
\hline 5. Poverty/hunger & 37 & 82 \\
\hline 6. Landless / homeless people & 2 & 4 \\
\hline 7. Alcohol/drugs & 21 & 47 \\
\hline 8. Maintenance & 12 & 7 \\
\hline 9. Marital problems & 9 & 20 \\
\hline 10. Domestic violence & 29 & 64 \\
\hline 11. Child and youth care & 25 & 56 \\
\hline 12. Crime & 3 & 6 \\
\hline
\end{tabular}

The above problems can be further grouped into three categories:

- HIV/AIDS (87\%) and its results, e.g. the many orphans in the community that need to be placed or taken care of by other relatives or grandparents. There is also the problem of childheaded families. Eighty-seven percent $(87 \%)$ of the social workers mentioned HIV/AIDS as a huge problem experienced by the rural communities.

- POVERTY (82\%) its consequences or causes. Here aspects such as unemployment (42\%), homeless/landless people $(4 \%)$ and crime $(6 \%)$ were mentioned. Unemployment amongst the young people was seen as a huge problem. In general the absence of crime is one of the reasons why some social workers prefer staying in a rural community, but in three 
communities crime was a big issue. Crimes like hijacking of cars and stock theft as well as theft of pensions and grant money were mentioned in particular. The crimes were poverty related and it was again the youth that were mainly involved in crime.

The problem of illiteracy $(20 \%)$ could also be added to the poverty category as it can be a cause and consequence of poverty. A concern social workers have regarding illiteracy is that the people remain uninformed, dependent and disempowered. They cannot really make informed decisions or claim their rights. The social workers explained that it was mostly the older people who are illiterate and consequently abused and easily exploited.

The lack of infrastructure and basic facilities, such as running water, electricity and housing are also aspects poverty.

- FAMILY ISSUES include domestic violence (64\%), child and youth care/abuse (56\%), child abandonment, street children, concern about children on farms, teenage pregnancies, marital problems (20\%) and maintenance problems (27\%). Alcohol and drug abuse are also included in this category as they are seen as a cause of marital problems and broken family relations (47\%). According to the social workers the problem of domestic violence has escalated over recent years.

In a study done by Masemola, Noeth, Risenga and Van Aardt (2003) in three rural areas in Mpumalanga province, they stated that the various police officers said that some of the most common crimes in the rural areas are domestic violence, assaults and rape. These crimes usually occur over weekends and there is a significant relationship between the abuse of alcohol and these violent crimes.

In one area the social workers mentioned a high incidence of child abandonment. This was due to young girls leaving the community to work in the city. After a while they bring back a baby, leave the baby with the grandparents and disappear again without any contact details. Apparently taxis are hired by unknown people, who take these girls away. Rumours spread that they work as prostitutes and domestic workers or may even be sold. The communities in that particular region refer to the "verniet taxi" or "free taxis" which come to collect these girls. I asked the social workers if they had ever investigated this further, but the response was negative. The underlying consequence of these problems is that the people experience no hope for the future.

\section{What do social workers' case loads consist of?}

The aim of the question was to explore which of the community problems mentioned by the social workers are brought to the offices of the social workers.

TABLE 2

PROBLEMS ADDRESSED

\begin{tabular}{|l|c|c|}
\hline \multicolumn{1}{|c|}{ Problems addressed } & Number & Percentage (\%) \\
\hline 1. Aids orphans/foster care & 41 & 91 \\
\hline 2. Maintenance (fathers not paying) & 8 & 18 \\
\hline 3. Domestic violence/family conflict (alcohol related) & 31 & 9 \\
\hline . Children related (abuse/abandonment/neglect) & 0 & 44 \\
\hline 5. Grants/poor relief/food parcels (aged/disabilities) & 20 & 44 \\
\hline
\end{tabular}


Approximately $91 \%$ of the social workers said that they did not deal with people with HIV/AIDS as such (e.g. Aids counselling), but with the results of HIV/AIDS, such as the orphans of the deceased mother and the deceased or unknown father and children who had to be placed in foster care. Most of their time went into statutory work and the placement of these children and all the administration that accompanies the foster placement. Some of the social workers mentioned that this was the only service they managed to render. I arrived at ten o' clock one morning at the office of a social worker in one of the remote rural areas and she mentioned that she had already done the 6th application for foster care that morning. The placement of these children is no simple procedure, as the grandparents or other relatives who might be used as foster parents are often illiterate and first need to apply for all the necessary documents, e.g. ID documents, death certificates, etc. The social workers often have to assist people in this process as well. This process is time-consuming and depends on the availability of the Department of Home Affairs. Another complicating factor in these foster placements in the rural areas is that there is not always a magistrate available to deal with the cases. In one area the social worker said that she had a backlog of a 100 foster placements to be finalised, because a commissioner who could legalise the placements was available only once a week. Another difficulty which delays the process is the lack of resources, such as transport.

The second biggest problem that people brought to the attention of the social workers centres on family and marital problems (69\%). This includes family conflict (including the extended family) and domestic violence. Without being able to give statistics, they mentioned that domestic violence is on the increase. This is due to the increase in poverty. The social workers often relate alcohol and family problems. Drug abuse amongst the youth was sometimes mentioned, but it did not seem as if this issue was really being dealt with by the social workers.

The problem of fathers not paying maintenance was mentioned by $18 \%$ of the respondents. In a specific rural area the social worker said that most of his work had to do with fathers who did not pay maintenance to their families. Close to the rural town was a big mining company which provided work and the unemployment rate in this area was very low. Family problems (including alcohol abuse) and non-maintenance were however the biggest complaints that people brought to the social worker. The results of the non-payment, such as poverty and the consequent lack of housing and food, are the issues that the social workers have to deal with. Partly due to the lack of a maintenance official in rural areas, the social worker is the person people turn to for help in dealing with this issue.

Most of the problems already mentioned are also seen as poverty-related problems (44\%), but the social workers were not really involved in poverty alleviation. In most of the areas community developers were appointed to develop income-generating projects for poverty alleviation. Where the social workers were dealing with the poverty issues directly, people tried to access some form of grant, e.g. foster-care grants, child-support grants, or old-age pensions. The abuse of grants is a further problem that social workers devote their time to. According to the social workers, people will do anything to access money. One social worker pointed out that it is also the responsibility of the social worker to investigate the circumstances of the families who applied for a pauper's funeral from the Department of Social Development. It is however of concern that community developers who are responsible for poverty alleviation do not involve social workers in this process. Trained social workers become administration officers processing applications for grants, while development officers who sometimes only have six months training do community development. 
Child-related problems (44\%) are of great concern to the social workers. These are mostly statutory cases. There were also some other programmes that were being run by social workers for example, parenting and life-skills for children. Some of the social workers also indicated that they were doing play therapy or would like to do play therapy as there is a great need for this.

When the social workers were probed to give an indication of the percentage of foster placements in their caseloads, they could not really give me a precise indication. These are some of their responses:

"I place 20 orphans per month"

Plus minus five social workers said that $50 \%$ of their placements were Aids orphans.

"9-10 applications per week. I have a backlog of a 100 placements which are not processed as we can go to court only once a week. No child commissioner is available”.

"I have placed 150 children since May" (As this was the beginning of September, that means 50 children per month for 3 months).

\section{5-20 foster care placements per month.}

150 children in statutory care of which most are orphans.

20-30 new applications per month.

$70 \%$ of the caseload is foster placements.

33 of 160 cases are foster care.

$80 \%$ of my caseload is foster care.

66 foster cases.

Three indicated that 90-98\% of their caseloads consisted of foster placements.

This does not imply that other problems do not exist. It means they do not have the time or the resources to attend to other people and their problems. Only those who have access to the social workers can be attended to.

\section{Size of the caseloads of the social workers}

Some of the social workers could immediately answer how many people they have on their caseloads. Some were unsure as they have long-term and short-term cases for which they do not necessarily open a file.

TABLE 3

\section{CASELOADS}

\begin{tabular}{|c|c|c|}
\hline Caseload & Number & Percentage (\%) \\
\hline $200+$ & 2 & 4 \\
\hline $150+$ & 9 & 20 \\
\hline $100+$ & 3 & 7 \\
\hline $50+$ & 11 & 24 \\
\hline $50-$ & 4 & 9 \\
\hline Could not give direct figures & 16 & 36 \\
\hline Total & $\mathbf{4 5}$ & $\mathbf{1 0 0}$ \\
\hline
\end{tabular}


As indicated in Table 3, 36\% of the social workers could not give clear figures of their caseloads. One of the social workers, for example, said that her long-term caseload was plus minus 50, but the figure could grow to 150 per month if she counted the people who came to ask for material assistance. The short-term intakes are usually grant applications or food assistance. These shortterm intakes and assistance ranged from 8 per week to 60-65 per month.

It was also remarkable that when I visited social workers in the same town, but from different organisations were contacted there would sometimes be a huge discrepancy in their caseloads. In one specific town one social worker's caseload was around 50, while her colleague from another agency had 150 cases. When I enquired about this situation, the social worker who had the 150 caseload said that she thought they were much more accessible to the people and had a more open, client-friendly image. Confidentiality was also more respected by the latter agency and people felt more secure about the services being rendered.

In four percent of the areas (4\%) the relatively "low" caseloads (less than 50), were surprising, especially if the problems the client system experienced were taken into consideration. This again could refer to the accessibility and/or attitude of the social worker.

\section{Social work services to farm workers}

One of my personal concerns is about the provision of social services to farm workers. I noticed that the social workers did not refer to farm workers as part of their perceived problem. I regard farm workers as one of the most unseen and "voiceless" groups, as Chambers (1997) would refer to them. When speaking of farm workers I refer to labourers on commercial farms. The farm usually belongs to a farmer or company, and the farm workers live on the farm. Small subsistence farmers who farm either on communal land or their own land are not included. The latter group do not employ farm workers, but do the work themselves. Atkinson (2001) confirms that the provision of services to farm workers has always been a difficult challenge:

1. Farm workers are marginalised as far as government funding is concerned because they live on private property.

2. The spatial distribution of farms makes the provision of services or infrastructure very expensive to deliver.

3. The dispersed nature of the farm-worker community makes it difficult to create farmworkers' forums.

Despite these factors, the provision of social services to farm workers remains an important issue, not only from the point of view of their human rights of health and dignity, but also to bolster the farming economy.

In this research it was investigated whether social workers render any social work services to farm workers. 
TABLE 4

SERVICES TO FARM WORKERS

\begin{tabular}{|l|c|c|}
\hline \multicolumn{1}{|c|}{ Services to farm workers } & Number & $\begin{array}{c}\text { Percentage } \\
(\mathbf{\%})\end{array}$ \\
\hline 1. No commercial farms in the area - no farm workers & 8 & 18 \\
\hline 2. Yes (including groups and awareness days at farm schools) & 3 & 7 \\
\hline $\begin{array}{l}\text { 3. Yes (mainly casework if the farmer or farmer's wife refer the } \\
\text { people to the social worker) }\end{array}$ & 13 & 29 \\
\hline 4. No service delivery Total & 21 & 46 \\
\hline \multicolumn{1}{|c|}{ Ton } \\
\hline
\end{tabular}

1. Eighteen percent $(18 \%)$ of the social workers do not work in an area where there are commercial farms; there are only subsistence farmers.

2. Seven percent (7\%) of the respondents indicated that they delivered services to farm workers in the form of awareness programmes (e.g. HIV/AIDS, life skills). This was mainly done through the farm schools. One NGO indicated that they offered awareness and educational programmes to farms.

3. In the third category $29 \%$ social workers indicated that they did deliver a casework service to the farm workers, but only if the farmer or the farmer's wife referred the people to their offices. Very seldom would a social worker visit the farm and then only when there was a serious case of child abuse and if they had a vehicle available.

4. Lastly, the biggest group (46\%) of respondents indicated that they did not deliver any services to, or facilitate any projects with, farm workers.

During the research some farmers were informally asked which services they would require from social workers. Casework to their farm workers is considered to be important, but a more comprehensive service such as the old Rural Foundation, where the focus was on the development of the farm worker, is needed. The approach by the Rural Foundation was mainly community development and the farmers experienced that they, as well as the farm workers, had benefited from the Rural Foundation's involvement.

What services should be rendered to farm workers and their families?

Based on the above information that limited services are rendered to farm workers, social workers were asked what problems they thought farm workers experienced and what services could or should be rendered to them. The social workers were very well aware of the situation of the farm workers and that they urgently needed assistance for serious social problems, e.g.:

- Child care and child guidance problems, alcoholism, marital problems and domestic violence;

- Illiteracy and the fact that they were unaware of their human rights and that education and training in this regard are necessary;

- Community work on farms as the quality of life of farm workers is very low.

One of the social workers mentioned that "...the farmers live too close to the farm workers to realise how bad their circumstances really are". 
Although some of the social workers indicated that the farmers are interested in the services of the social workers, they do not have the time or resources to attend to them. One farmer stated: "We do not look after the farm workers. There will be too many needs if we start looking".

The social workers often experience problems in accessing some of the farms as well as finding suitable time to attend to farm workers. It has to be either after hours or during lunchtime as the farmers cannot afford the farm workers to be away from their work during working hours. To work after hours seems to be problematic and often the social workers do not have transport to visit the farms. The farms are also far apart and travelling is time-consuming. They therefore only attend to serious problems, like child abuse. In one area the social worker regards the farm workers as being the responsibility of the environmental officer. Some of the social workers do not feel safe travelling the long distances to the farms on their own. Du Plessis (2002) however cited excellent examples of the services that could be implemented to farm workers.

\section{Difficulties experienced of working in rural areas}

Gumpert and Saltman (1998) describe the problems unique to rural practice as follows:

- confidentiality;

- people value their self-reliance;

- large distances social workers have to travel;

- weather conditions;

- insufficient number of people with the same problem;

- lack of public and private transport;

- lack of childcare and other facilities or infrastructure.

On questioning the social workers in this research their responses can be organised in the following themes:

TABLE 5

DIFFICULTIES EXPERIENCED

\begin{tabular}{|l|l|l|}
\hline Difficulties experienced & Number & Percentage (\%) \\
\hline 1. No resources and infrastructure & 34 & 76 \\
\hline 2. People do not understand the role of social workers & 8 & 18 \\
\hline 3. Travelling long distances & 12 & 27 \\
\hline 4. Lack of support & 4 & 9 \\
\hline $\begin{array}{l}\text { 5. Viewing social workers as the "dustbin"/“ashoop" of the } \\
\text { community }\end{array}$ & 5 & 11 \\
\hline 6. Cultural issues and traditional structures & 8 & 18 \\
\hline
\end{tabular}


The themes that emerged were actually quite interesting in comparison with other literature. The problems around confidentiality that Gumpert and Saltman (1998) mentioned were not mentioned spontaneously by these social workers, but only after they were probed.

\section{The lack of infrastructure and resources}

Seventy-six percent $(76 \%)$ indicated that the lack of infrastructure and resources were the most difficult aspects. This included lack of proper transport to access clients (Rankin, 1992; Schenck, 2003).

\section{The role of the social worker}

In the second theme, $18 \%$ of the respondents experienced that the communities did not understand which services social workers were supposed to render. Twente (1980:297) refers to Strode who listed 371 duties that a social worker can deliver: from working with children, adults, the mentally ill, the aged, prisoners, to arranging home visits, grants, funding projects, administration, networking, etc. Strode confirms that social workers are usually in the firing line of the problems of the community. The social workers in this research felt that they were seen as the persons who issued grants or through which grants could be accessed due to the poverty that exists in the rural communities. Masemola et al. (2003) confirm this in their research report.

"In comparison to most professions, social work is a more expansive umbrella covering a tremendous array of activities and dealing with a variety of problems."

The result of this array of activities is that social workers need to be multi-skilled. They have to be able to do everything. A social worker is expected to be a "Jack of all trades" and a generalist. The social workers however, experience frustration because they rather prefer to be specialists.

\section{Travelling and distances}

Travelling long distances was mentioned by $27 \%$ of the social workers as being very difficult. It is time-consuming and in some instances unsafe to travel alone, and as most of the social workers are females, they do not feel safe doing so. The long distances and lack of transport also make them inaccessible to the community.

\section{Lack of support}

Nine percent $(9 \%)$ of the social workers mentioned lack of support from their supervisors, or organisation as problematic(Schenck, 2003).

\section{5. "Dustbin"/"asblik"}

Linked to the undefined role of the social workers, $11 \%$ of them felt responsible for all the problems in the community which could not be solved by the chief, ministers of religion or relatives. They were the "dustbin" or the "asblik/ashoop" of the community and the last resort and if they could not solve the problems, their effectiveness was questioned.

\section{Cultural issues}

Traditional and cultural issues were mentioned by $18 \%$ of the social workers as being difficult aspects. It was mainly the black social workers who raised cultural and traditional issues. Three aspects were mentioned. 
The one frustration came from the cultural practices of people in the black communities who, when they experienced problems, first had to consult their relatives, then the chief or induna, who would then refer the people to the social worker. This links up with the "dustbin" experience.

The second frustration was experienced by some black social workers who worked amongst a cultural group which was different from their own. They were very critical about some of the community's cultural practices. This came as a surprise to me as I thought that their social work training would have prepared them to accept people from a different ethnic or cultural group and that they would view this as a learning opportunity.

Tradition and culture made it difficult to bring change to rural communities.

\section{Confidentiality}

Confidentiality implies that the information which a social worker receives from a client or the community will not be revealed without the explicit consent of the client or community. Confidentiality is the right to privacy.

As Gumpert and Saltman (1998) and each and every social worker in this research indicated, confidentiality is an enormous problem in rural communities (also see Davenport \& Davenport (1995); Ginsberg (1998); Miller (1998)). Martinez-Brawley (2000:253) quotes Kirk and Irey (1981)

"The issue of confidentiality within the social context is especially acute in rural environments. In small towns and communities, social workers and clients must function not only in therapeutic sessions but also in daily interactions within circumscribed social systems".

The following situations were described by the social workers:

- Sometimes information that the social worker assumes is confidential is already public knowledge. If a member of the public talks to the social worker about a certain issue, she cannot deny knowing about it, but if she mentions it first they will realise that she is aware of it and may want to know more. She is then in the difficult position of admitting knowing about a situation, but being unable to comment or share views about it.

- Social workers often visit remote rural communities where they do not have an office in which to see clients. Consequently they visit these clients in their homes, or talk to them under a tree or in the social worker's car. The rest of the community can see who experiences problems.

- Anonymity can be quite difficult for the clients who do not want the people to know that they are seeing the social worker. The secretaries working in the social worker's office are usually from the rural community. These people have access to clients' files, type reports and know the people in the waiting room. They may be aware of problems involving people in the community and may bring them to the attention of the social workers. Confidentiality issues regarding people who work closely with the social workers need to be addressed.

- Davenport and Davenport (1995) mention with regard to the above situation that confidentiality in a small town is a big problem as it is easy for the people to see who is visiting the social worker's office. Curious people may ask the social worker in the street or at a social event "What is wrong with that person?" The social workers shared how cleverly some of the people may phrase a question to get you in a position where you can be caught off guard and may share information or admit that you know or have seen a certain member of the community. They will ask you questions like "I saw you with Mr and Mrs B last week. How 
are they?" Davenport and Davenport (1995) suggest that you can deal with an issue like this as follows: "I am glad you are concerned about Mr... but I may not give you any information".

- To prevent people in the community from seeing that a person is visiting the social worker or that the social worker is visiting a client, some of the clients will go to the house of the social worker to give the impression that they are friends, intruding on the privacy of the social worker.

- A very common situation experienced by the social workers is that people will stop you in the shop/street and start talking about their problems. In some communities it seems as if certain problems are public knowledge and some problems are private matters. If your husband beats you, it could be a public matter but sexual problems will be a private matter. In some communities the social worker will find that the application to adopt a child can be a public matter, but in other cultures this is an indication of sexual problems or inability (infertility) and is a highly private matter.

- Drawing boundaries between the social worker and volunteers regarding confidential information is another possible trap which has to be dealt with carefully.

- Some of the social workers say that they avoid shopping in the town where they work to prevent meeting their clients in a shop. If you greet a client, it may be an acknowledgement to the people that you know this person and that he may be one of your clients. The social workers who reside in the community and meet clients in a shop indicated that they wait until the client greets them first before they greet them back.

- The social workers also indicated that the cars they drive also give away that a social worker is visiting the family. One social worker who worked with disabled people said that the people referred to her car as the "gestremde kar" or "disabled car" and in other instances it would be the "welfare car".

- Another confidentiality issue mentioned was that social workers often had to share offices and facilities like computers with other officials. Social workers sharing offices would have to conduct an interview in front of another social worker as there was nowhere else they could go. In one particular office I found two social workers sharing an office, even though they both had offices. It was a cold and rainy day and they were sitting huddled around a heater conducting their interviews. One of the social workers said that her office was too cold. In another office that I visited the social worker and her administrative assistant were sharing the same office. The social worker also interviewed her clients in the presence of the administrative officer. The social worker initially denied this practice, but later acknowledged that it was taking place as there was no other place for the administrative assistant to wait and she could not continue with her work if she had to leave the office. The office also did not have a waiting room for the clients. They were sitting under a tree outside the office despite the fact that the office was part of a clinic.

- Some social workers were concerned about the fact that they shared computers with other officials, e.g. the social security officials. The implication is that these officials could access confidential information, e.g. reports written by the social worker. The social workers admitted that they were not computer literate enough to create their own secure files. They have to work on the computer without any training.

- In some offices confidentiality was violated as the offices were not soundproof, because the walls were not built up to the roof. Another problem was that one had to walk through one 
office to reach the next. In order to reach her office, the social worker had to take her clients through the office of another social worker who might be busy with clients of her own. One social worker, who did not have a solid wall between her office and the reception area, told me that she and the clients had to whisper, otherwise clients in the waiting room would hear and even make comments.

These incidents illustrate how the lack of proper facilities in rural (and other) areas can create critical confidentiality problems. My assumption is that this reflects an organisation's basic lack of respect for people when they do not provide proper facilities, where social workers can at least apply the basic principles and values of social work.

Other confidentiality dilemmas that the rural social workers mentioned were the following:

- To understand the context of the following dilemma mentioned by the social workers, it has to be seen against the background of the political situation in certain rural areas where there is competitive friction between political structures and traditional structures. The social workers mentioned certain difficult dilemmas they experienced when these "political" leaders demanded information from them regarding certain cases, e.g. rape cases which could be used for political gain or for "bundu/kangaroo" courts. The social workers were threatened by these people if they did not provide this information.

- Clients do not protect confidential information. They do not keep quiet about whom they met at the social worker's office. The social workers say that sometimes the clients may accuse them of telling the people in the community who was at their office.

- A social worker mentioned that he experienced a confidentiality problem once when using a note through which he invited people to come and see him at the office. The person at the post office realised that the letter came from the welfare organisation and commented on this to the client. This resulted in the client being extremely upset about it.

\section{SUMMARY AND RECOMMENDATIONS}

None of the information in this study is entirely new. The reader may not find anything new, but merely a confirmation of what is already known or suspected (Twente, 1980). There is, however, hope that this study will bring about an awareness and concern for the rural people and rural social workers who have to take up the challenge. They must become part of cutting-edge research and help to bring about change to facilitate social and economic development in rural communities. This implies that the social workers themselves should become critically aware of their own realities and roles. This can be accomplished with the facilitative attitude of training institutions and the welfare organisations. More research is necessary to obtain more detailed knowledge and to find more solutions for some of the critical problems.

It is critical to establish a forum or voice for rural social workers, where we could listen to them and plan the way forward to address the special issues they have to deal with.

\section{BIBLIOGRAPHY}

ALSTON, M. 2000. Rural Poverty. Australian Social Work, 53(1):29-34.

ATKINSON, D. 2001. Farm worker development: paradigms, policies and delivery systems. HSRC Research Proposal.

CHAMBERS, R. 1997. Who's reality counts. London: ITP. 
CHENOWETH, L. \& STEHLIK, D. 2001. Building resilient communities: social work practice in rural Queensland. Australian Social Work, 54(2):47-54.

CHIPKIN, I. 2002. A developmental role for local government. In: PARNELL, S.; PIETERSE, E.; SWILLING, M. \& WOOLDRIDGE, D. Democratising local government: the South African experiment. Cape Town: UCT.

DAVENPORT, J.A. \& DAVENPORT, J. 1995. Rural Social work overview. In: EDWARDS, R.L. (ed) Encyclopedia for Social Work. Washington DC: NASW.

DU PLESSIS, R. 2002. The narrative approach and community development: a practical illustration. Africanus: Journal of Development Studies, 32(2):76-92.

GINSBERG, L.H. 1998. Introduction: an overview of rural social work. In: GINSBERG, L.H. (ed) Social work in rural communities. $\left(3^{\text {rd }}\right.$ ed) Alexandria VA Council on Social Work Education, 3-22.

GUMPERT, J. \& SALTMAN, J.E. 1998. Social group work practice in rural areas: the practitioner speak. Social Work with Groups, 21(3):19-32.

LONNE, B. \& CHEERS, B. 2000. Rural social workers and their jobs: an empirical study. Australian Social Work, 53(1):21-27.

MARTINEZ-BRAWLEY, E.E. (ed) 1980. Pioneer efforts in rural social welfare: first hand views since 1908. University Park: The PSU.

MARTINEZ-BRAWLEY, E.E. 1998. Community oriented practice in rural social work. In: GINSBERG, L.H. (ed) Social Work in rural communities. ( $3^{\text {rd }}$ ed) Alexandria VA Council on Social Work Education, 99-113.

MARTINEZ-BRAWLEY, E.E. 2000. Close to Home: human services and the small community. Washington DC: NASW.

MASEMOLA, E. NOETH, A. RISENGA, A. \& VAN AARDT, C. 2003. Draft project report on a situation analysis of service providers and existing services to people infected and affected by HIV/AIDS. Unpublished Report of the Bureau for Market Research, Unisa.

MAYER, A.G.K. 2001. Rural social work: the perceptions and experiences of five remote practitioners. Australian Social Work, 54(1):91-102.

MILLER, P.J. 1998. Dual relationships in rural practice: a dilemma of ethics and culture. In: GINSBERG, L.H. (ed) Social Work in rural communities. $\left(3^{\text {rded }}\right)$ Alexandria VA Council on Social Work Education.

MORALES, A.T. \& SHEAFOR, B.W. 1998. Social work: a profession with many faces. $\left(8^{\text {th }}\right.$ ed) Boston: Allyn Bacon.

PENNYPACKER, E.K. 1980. No one can do everything. In: MARTINEZ-BRAWLEY, E.E. (ed) Pioneer efforts in rural social welfare: first hand views since 1908 University Park: The Pennsylvania State University: 393-398.

PYCROFT, C. 2002. Addressing rural poverty: restructuring local government. In: PARNELL, S.; PIETERSE, E.; SWILLING, S. \& WOOLDRIDGE, D. Democratising local government: the South African experiment Cape Town: UCT.

RANKIN, P. 1992. Resource development as a priority in rural areas: the role of the social worker. Social Work/Maatskaplike Werk, 28(3):36-47. 
ROUNDS, K.A. 1998. AIDS in rural areas: challenges to providing care. In: GINSBERG, L.H. (ed) Social Work in rural communities. ( $3^{\text {rd }}$ ed) Alexandria VA Council on Social Work Education.

SCHAFER, C.L. 1980. This is rural social work. In: MARTINEZ-BRAWLEY E.E. (ed) Pioneer efforts in rural social welfare University Park: The Pennsylvania State University.

SCHENCK, C.J. 2003. Rural social work in South Africa. Unpublished research report [schencj@unisa.ac.za]

SEWPAUL, V. 2002. Broadening horizons through international exchanges: global and local discourses in the development of critical consciousness Paper delivered at the JUC 2002 Potchefstroom.

STRODE, J. 1980. An open letter to Miss Bailey: rural social workers do everything. In: MARTINEZ-BRAWLEY E.E. (ed) Pioneer efforts in rural social welfare University Park: The Pennsylvania State University.

STRODE, J. 1980. Learning from the job. In: MARTINEZ-BRAWLEY, E.E. (ed) Pioneer efforts in rural social welfare. University Park: The Pennsylvania State University.

TABACK, R. \& TRIECHAARDT, J.P. 1992. Educating social workers to practice in rural South Africa: dilemmas and challenges - A case study. Social Work/Maatskaplike Werk, 28(4):91-94.

TWENTE, E.E. 1980. Social casework practice in rural communities. In: MARTINEZBRAWLEY, E.E. (ed) Pioneer efforts in rural social welfare. University Park: The Pennsylvania State University.

WEAVER, W.W. 1980. A preface to rural social work. In: MARTINEZ-BRAWLEY, E.E. (ed) Pioneer efforts in rural social welfare University Park: The Pennsylvania State University.

WOODS, R. 1992. Training of social work assistants in and for rural areas: the Hungarian "szocialis asszisztens" as a model for south Africa's rural social services. Social Work/Maatskaplike Werk, 28(3):29-35.

YORK, R.O.; DENTON, R.T. \& MORAN, J.R. 1998. Rural and urban social work practice: is there a difference? In: GINSBERG, L.H. (ed) Social work in rural communities. Alexandria VA Council on Social Work Education. 